\title{
UNDERSTANDING PLANT DENSITY EFFECTS ON MAIZE GROWTH AND DEVELOPMENT: AN IMPORTANT ISSUE TO MAXIMIZE GRAIN YIELD
}

\author{
A COMPREENSÃO DOS EFEITOS DA DENSIDADE DE PLANTAS SOBRE O CRESCIMENTO \\ E DESENVOLVIMENTO DO MILHO É IMPORTANTE PARA MAXIMIZAR \\ O RENDIMENTO DE GRÃOS
}

\author{
Luís Sangoi ${ }^{1}$
}

\section{REVISÃO BIBLIOGRÁFICA}

\section{SUMMARY}

Maize is the agronomic grass species that is most sensitive to variations in plant density. For each production system, there is a population that maximizes grain yield. This article presents an overview of the factors that affect optimum plant population, emphasizing the effects of dense stands on ear development and discussing important changes in plant traits that have contributed to increase the tolerance of modern hybrids to high plant densities. Population for maize maximum economic grain yield varies from 30,000 to over 90,000pl.ha-1, depending on water availability, soil fertility, maturity rating, planting date and row spacing. When the number of individuals per area is increased beyond the optimum plant density, there is a series of consequences that are detrimental to ear ontogeny and result in barrenness. First, ear differentiation is delayed in relation to tassel differentiation. Later-initiated earshoots have a reduced growth rate, resulting in fewer spikelet primordia transformed into functional florets by the time of flowering. Functional florets extrude silks slowly, decreasing the number of fertilized spikelets due to the lack of synchrony between anthesis and silking. Limitations in carbon and nitrogen supply to the ear stimulate young kernel abortion immediately after fertilization. Availability of earlier hybrids, with shorter plant height, lower leaf number, upright leaves, smaller tassels and better synchrony between male and female flowering time has enhanced the ability of maize to face high plant populations without showing excessive barrenness. Improved endurance in high stands has allowed maize to intercept and use solar radiation more efficiently, contributing to the remarkable increase in grain yield potential experienced by this crop.

Key words: Zea mays, plant population, crowding, barrenness

\section{RESUMO}

O milho é a gramínea mais sensível a variações na densidade de plantas. Para cada sistema de produção, existe uma população que maximiza o rendimento de grãos. Este artigo apresenta uma revisão sobre os principais fatores que afetam a densidade ótima, enfatiza o efeito de densidades elevadas no desenvolvimento das espigas e discute as características de planta que contribuíram para aumentar a tolerância dos híbridos modernos de milho a populações elevadas. A população ideal para maximizar o rendimento de grãos de milho varia de 30.000 a 90.000pl.ha ${ }^{-1}$, dependendo da disponibilidade hídrica, fertilidade do solo, ciclo da cultivar, época de semeadura e espaçamento entre linhas. Quando o número de indivíduos por área é superior à densidade ótima, há uma série de consequiências negativas para a formação da espiga que podem levar a esterilidade. Primeiramente, a diferenciação da espiga é retardada em relação à diferenciação do pendão. Espigas diferenciadas tardiamente apresentam uma taxa reduzida de crescimento, transformando poucos primórdios de espiguetas em floretes funcionais durante a floração. Os floretes funcionais apresentam uma exteriorização dos estigmas mais lenta, diminuindo o número de espiguetas que serão fertilizadas devido à falta de coincidência entre antese e espigamento. Limitações no suprimento de carbono e nitrogênio às espigas estimulam o aborto de grãos incipientes logo após a fertilização. O lançamento de híbridos mais precoces, de porte reduzido, menor número de folhas, folhas mais eretas, tamanho reduzido do pendão e melhor sincronia entre o desenvolvimento das inflorescências masculina e feminina aumentou a habilidade da planta de suportar populações elevadas sem apresentar níveis expressivos de esterilidade. A maior adaptação do milho ao adensamento permitiu-lhe interceptar e utilizar a radiação solar mais eficientemente, contribuindo para o notável incremento no rendimento potencial de grãos dessa cultura.

Palavras-chave: Zea mays, população de plantas, adensamento, esterilidade.

\footnotetext{
${ }^{1}$ Engenheiro Agrônomo, PhD., Professor da Universidade do Estado de Santa Catarina, CP 281, 88520-000, Lages, SC, Brazil. E-mail: a2ls@cav.udesc.br. Author for correspondence.
} 


\section{INTRODUCTION}

Within the grass family, maize is likely the species that presents the highest grain yield potential. In order to fully explore its capacity to transform solar radiation into grain production, it is necessary to understand how plants interact morphologically and physiologically in a community and to identify management practices which allow them to maximize the use of growth resources in their environment.

Plant density is one of the most important cultural practices determining grain yield, as well as other important agronomic attributes of this crop. Stand density affects plant architecture, alters growth and developmental patterns and influences carbohydrate production and partition (CASAL, 1985). Maize is more sensitive to variations in plant density than other members of the grass family (ALMEIDA \& SANGOI, 1996). At low densities, many modern maize hybrids don't tiller effectively and quite often produce only one ear per plant. Therefore, maize does not share the trait of most tillering grasses of compensating for low leaf area and small number of reproductive units by branching (GARDNER et al., 1985). On the other hand, the use of high populations heightens interplant competition for light, water and nutrients. This may be detrimental to final yield because it stimulates apical dominance, induces barrenness, and ultimately decreases the number of ears produced per plant and kernels set per ear (SANGOI \& SALVADOR, 1998a).

For each production system, there is a population that maximizes the utilization of available resources, allowing the expression of maximum attainable grain yield on that environment. The purpose of this article is to present an overview of the factors that affect optimum maize population and grain yield, to discuss the effects of higher than optimum plant population on yield definition, and to pinpoint modifications of plant attributes that have contributed to improve maize adaptation to high plant densities.

\section{Factors affecting optimum population density:}

Maize population for maximum economic grain yield varies between 30,000 to over 90,000 plants per hectare (OLSON \& SANDERS, 1988). There is no single recommendation for all conditions because optimum density varies depending on nearly all environmental factors as well as on controlled factors, such as soil fertility, hybrid selection, planting date and planting pattern, among others. A brief summary of some of the variables that can influence optimum population follows.

\subsection{Cultivar maturity and length of the growing} season:

Generally speaking, early hybrids require higher plant densities for maximum yield than late hybrids (SILVA, 1992; TOLLENAAR, 1992). This occurs because early hybrids are normally smaller, produce less leaves, have lower leaf area per plant and present fewer self-shading problems than late cultivars. Therefore, for early hybrids it is necessary to have a greater number of plants per area to generate the leaf area index that provides maximum interception of solar radiation, an essential step to maximize grain yield.

The season length in any particular geographic location is a factor that interacts with cultivar maturity, affecting the optimum rate of planting for maximum yield. There is evidence that higher plant densities are required in the Northcentral U.S. compared with locations further South (OLSON \& SANDERS, 1988). This is expected because available light energy decreases as one proceeds further North. Hence, the smaller amount of solar radiation and the shorter growing seasons registered in the Northern Maize Belt force the utilization of early varieties, contributing to increase optimum plant densities in those regions. The same kind of trend has been observed by MEROTTO Jr. et al. (1997a) and ALMEIDA et al. (2000) in the high-lands of Southern Brazil. Late Spring and early Fall frosts decrease maize growing season duration in this region. Mild Spring and Summer temperatures restrict maize vegetative growth. Both factors contribute to enhance maize grain yield response to higher plant populations (ALMEIDA \& SANGOI, 1996).

\subsection{Time of planting:}

Holding all other factors constant, earlyplanted maize usually requires a higher population to maximize yield, particularly in temperate and subtropical regions of the world (ALDRICH et al., 1986; ANDERSON, 1995). Early-planted maize encounters lower soil and air temperatures during its first developmental stages. The small number of thermal units accumulated per day makes it grows slowly (SANGOI, 1993). The period between emergence and anthesis of a maize hybrid planted in August can be up to two weeks longer than when the same cultivar is planted in December in Southern 
Brazil (SANGOI, 1993). During this extra period, plants will uptake more solar radiation and store the energy because the lower temperatures limit their growth and consumption of this energy. As a result of this slower pattern of development, early-sowed maize plants are smaller and less leafy at anthesis (SANGOI et al., 1998a; SILVA et al., 1998). Since early planting generally results in shorter plants that have lower individual leaf area, increasing plant density by 5,000 to 7,500 plants.ha $^{-1}$ is usually necessary to maximize yield (ALDRICH et al., 1986). Early planted maize also silks earlier in the growing season, when the atmospheric evaporative demand is usually smaller (MATZENAUER $\boldsymbol{e t}$ al., 1998), decreasing the probability of moisture stress, which can be another reason for early-planted maize higher tolerance to increased plant population.

\subsection{Water availability:}

Water availability is probably the most important uncontrollable factor affecting optimum plant density for maize grain yield under rainfed production systems (LOOMIS \& CONNORS, 1992). Precipitation, soil water and plant population interact, particularly during the rapid growth period of the crop (from $30 \mathrm{~cm}$ height to silking). The final effect on yield of these three interacting factors is determined by the level of soil water available to plants at the beginning of rapid growth period, by the amount and distribution of precipitation during this period and by the amount of water transpired by the canopy (MATZENAUER, 1998).

Increasing plant density increases leaf area index and consequently water consumption (TETIO-KAGHO \& GARDNER, 1988a). Therefore, the use of high plant populations under limited water supply may increase plant water stress and dramatically reduce grain yield, specially if a water shortage coincides with the period of 2-3 weeks bracketing silking (WESTGATE, 1994). Even though the increase in water use as plant density is raised is not proportional to the stand increase, small deficits during critical stages, especially at flowering, can drastically reduce kernel set and grain yield. Consequently, it is extremely important to consider water supply to define the optimum plant population for any particular region and cropping system. Shallow soil profiles, high atmospheric temperatures and irregular precipitation distribution favor drought stress. Under these circumstances, it is advisable to work with a lower number of individuals per area. This will decrease interplant competition for water, preventing a protandrous pattern of development that could lead to barrenness (SANGOI \& SALVADOR, 1998b).

\subsection{Row spacing:}

Ideally, plants spaced equidistantly from each other compete minimally for nutrients, light and other growth factors (LAUER, 1994). The introduction of hybrids, the increase in fertilizer utilization, the development of new herbicides to control weeds, among other factors, stimulated the use of higher plant densities in maize (RUSSELL, 1991)

With the utilization of higher plant densities, it soon became clear that plant distribution within the row could be a limiting factor in wide rows, preventing the full expression of the yield potential of new cultivars. Narrower spacing of rows is a partial mean of achieving equidistant spacing between maize plants (LAUER, 1994). Narrow rows make more efficient use of available light and also shade the surface soil more completely during the early part of the season while the soil is still moist (BULLOCK et al., 1998). This results in less water being lost from the soil surface by evaporation.

Therefore, reducing row width to provide a more equidistant planting pattern has the potential to increase maize yield and shift optimum plant population to a higher value depending on the interactions with management and environmental factors. The utilization of row spacing ranging from 0.5 to $0.75 \mathrm{~m}$ may enhance maize optimum plant population especially when highly productive singlecross early hybrids are grown in soils with high fertility and under irrigation (SANGOI et al., 1998a). Conversely, BUNTZEN (1992) and MEROTTO Jr. et al. (1997a) have shown that when any environmental factor or inappropriate management practice hinders maize growth and development, narrowing row spacing may have little effect on either improving grain yield or increasing the optimum plant population density necessary to maximize yield.

\section{High plant populations, ear development and yield restrictions in maize:}

Maize grain yield declines when plant density is increased beyond the optimum plant density primarily because of decline in the harvest index and increased stem lodging (TOLLENAAR $\boldsymbol{e t}$ al., 1997). Such cases represent intense interplant competition for incident photosynthetic photon flux density, soil nutrients and soil water. This results in limited supplies of carbon and nitrogen and 
consequent increases in barrenness and decreases in kernel number per plant and kernel size (LEMCOFF \& LOOMIS, 1994).

Maize yield development is a sequential process in which the potential number of ears per plant is determined first, followed by grain number per inflorescence and by grain size. Therefore, variations in the level of carbon and nitrogen induced by different planting rates, or any other factor, can strongly influence yield and its components sequentially (JACOBS \& PEARSON, 1991). Following is a brief description of the mechanisms by which high plant populations stress ear formation.

\subsection{Ear differentiation:}

One of the major factors limiting optimum conversion of light energy to grain in maize grown at high plant densities is barrenness, the failure of plants to produce viable ears (SANGOI, 1996). A clear understanding of ear development, from its differentiation to silking is essential to explain population effects on the number of female inflorescences produced per plant and the number of viable differentiated spikelets.

The first physiological alteration that can be associated with barrenness in high plant populations is a delay in ear differentiation and growth of ear primordia (JACOBS \& PEARSON, 1991). The number of functional earshoots differentiated per plant appears to depend upon the genetic programming for the time interval between the initiation of female inflorescences (lateral branches) and the differentiation of the shoot apex into a reproductive structure (male apical inflorescence). High rates of planting slow the rate of growth of axillary buds more than they do the shoot apex. The existence of this time interval permits the establishment of differential rates of polar transport of growth-promoting substances and nutrients into the shoot (SANGOI et al., 1996). These growth-promoting substances and nutrients would regulate the rate and pattern of earshoot development and the number of functional earshoots per plant. Later-initiated earshoots may receive smaller amounts of such substances, thereby having less chance to become functional and produce grains. Thus, the lower absolute growth rate observed for ears in dense populations can also result from increased competition for assimilates between the ear and the rest of the plant.

Besides the competition for assimilates among plant organs, there may be a hormonal mechanism accounting for the influence of plant population on ear development before flowering (WILLSON \& ALLISON, 1978). The maize shoot apex is differentiated into a tassel primordium when the plant has six to seven expanded leaves and is 40 to $50 \mathrm{~cm}$ tall (RITCHIE \& HANWAY, 1992). Once the growing point is transformed into a reproductive structure, it starts producing large amounts of phytohormones, especially auxins, which stimulate cell division and enlargement, triggering an intense increase in plant height and dry matter production. Under high densities less solar radiation reaches the growing point than under low densities (GARDNER et al., 1985). Light in high intensity or amount may oxidize and inactivate auxins (SALISBURRY \& ROSS, 1992). Therefore, under high densities there is less auxin inactivation and greater concentration of bioactive hormone. The tassel requires a greater auxin concentration for its development than the ear (SANGOI \& SALVADOR, 1997). Therefore, high plant population may promote hormonally-mediated apical dominance over the ears, contributing to barrenness (SANGOI \& SALVADOR, 1998b).

In addition to the auxin-mediated apical dominance effect, it is also important to consider the mediating role of phytochrome in sensing the degree of canopy closure. Research carried out with several species has shown that photomorphogenic light, primarily the ratio of far-red (FR) relative to red (R), can act through phytochrome among competing growing plants, regulating partitioning and morphological adaptation (ALMEIDA, 1998).

When plant density is increased, plants are closer to each other which enhances the amount of FR reflected by competing seedlings, leading ultimately to a higher FR/R ratio (KASPERBAUER \& KARLEN, 1994). An increased FR/R ratio derived from close-spaced plants suppress the development of tillers in wheat (ALMEIDA, 1998), stimulating apical dominance. Since maize ears are formed at the tip of lateral branches that are morphologically analogous to wheat tillers, barrenness can also be promoted by modifications in light quality induced by plant density modifications. The phytochrome system within the plant function as a sensor of competition. An intense crowding increases the FR/R ratio, triggering physiological events that will lead to prioritization in the allocation of new photoassimilates to the main stem, resulting in the suppression of lateral branches such as tillers or earshoots.

\subsection{Spikelet differentiation}

The delay in ear initiation observed in dense populations may subsequently impact the number of kernels produced per ear. The change in 
population can influence final kernel set through effects on the developing ear before flowering, on pollination and fertilization, and during early stages of grain filling.

There has been some controversy regarding the role of spikelet differentiation in grain yield reduction at high plant densities. WILSON AND ALLISON (1978), studying two contrasting plant populations $\left(2.47\right.$ and 4.94 plants $\left.\mathrm{m}^{-2}\right)$, observed that differentiation rate and final number of spikelet primordia were about the same in both plant densities. However, perhaps as a consequence of the delay in the initiation of the ears, fewer primordia developed into normally functional florets by the time of flowering in the dense population. LEMCOFF \& LOOMIS (1986) also pointed out that plant density effects on the variation of grain number were due primarily to variation in grain set and not in the number of spikelet primordia. The potential number of spikelets is established when spikelet formation ceases a few days before silking, while the number of developing kernels can diminish throughout the first three weeks after silking. Following this ontogenic sequence, TOLLENAAR \& DAYNARD (1978) supported the view that the number of initiated spikelets is not limiting to grain yield in maize. Rather, these authors believe that sink reduction occurs after formation of primordia, through abortion of spikelets, lack of pollination and fertilization or abortion of young kernels.

Contrary to all the authors reported in the previous paragraph, JACOBS \& PEARSON (1991) observed that the reduction in kernel number per ear under population, defoliation or nitrogen stress was partially due to a reduction in the number of spikelets differentiated per ear. The failure of spikelets to differentiate may be due to the need of a minimum surface area on the cob for each spikelet, with the density of spikelets remaining relatively constant over a wide range of environmental situations. There would be a need for a minimum space for the formation of spikelets, which could be altered by population stress.

The apparently contradictory data on the relative contribution of spikelet differentiation to yield definition may be related to the region where genotypes come from and to whether yield restrictions at high plant populations are primarily due to source or sink limitations. According to SALVADOR (1984), tropical hybrids are typically sink-limited whereas temperate hybrids are normally source-limited. Therefore, yield definition dynamics differ according to whether Canadian, Mexican or Brazilian materials are been examined. The occurrence of barren tips when low stem sugar concentration occur provides evidence that insufficient assimilates during grain filling account for barrenness (source limitation), whereas the presence of rudimentary spikelets at the flowering time points toward growth limitation occurring during late ear formation (sink limitation).

\subsection{Spikelet fertilization:}

Another very important factor for kernel set and yield determination is the number of differentiated spikelets that are actually fertilized. Plant population influences synchrony of flowering and hence grain yield. High plant densities may reduce the supply of nitrogen (LEMCOFF \& LOOMIS, 1994), photosynthates (JACOBS \& PEARSON, 1991) and water (WESTGATE, 1994) to the growing ear. Restrictions in carbon or nitrogen metabolism and drought stress may delay specific developmental events and reduce both spikelet number and silk extrusion, contributing to decrease the number of spikelets that can be fertilized through coincidence of pollen shed with silking of individual spikelets (JACOBS \& PEARSON, 1991). Thus, barrenness and the production of nubbin ears, associated with increasing plant population, have been linked with delayed silk or growth of ear primordia. Lengthening of the time interval between anthesis and silking associated with increasing population has been reported by LEMCOFF \& LOOMIS (1986), PEIXOTO et al. (1997) and SILVA et al. (1998).

Given the indeterminate nature of ear development in modern maize cultivars, protandry is a key factor in the determination of kernel number, particularly affecting spikelets that are developed at the distal part of the ear (SALVADOR., 1984). Adverse conditions such as high plant population, water stress and nitrogen deficiency slow silk development. Length of stigmas is mainly by cell extension after an early period of cell division in the basal zone (WESTGATE, 1994). Reduced silk extrusion rate may be due either to restricted cell division (LEMCOFF AND LOOMIS, 1994) or cell elongation (WESTGATE \& THOMSON, 1989). Under adverse conditions such as high population stress, some late developing distal spikelets always fail to set kernels. When their slow growing silks finally emerge, little or no pollen is available for fertilization.

\subsection{Abortion of young kernels:}

The number of potential kernels produced per ear at high plant population is also reduced by abortion of recently fertilized ovaries. Soluble sugars 
and organic nitrogen are important substrates for growth of the developing grain (SWANK $\boldsymbol{e t} \boldsymbol{a l}$., 1982). Their absolute amounts in the developing ears and proximate organs during the critical ontogenic stages between pollen release and the beginning of effective grain filling is critical for the initial growth of the fertilized kernels, serving as a basis to explain variations in yield (LEMCOFF \& LOOMIS, 1986). Therefore, high plant densities may promote limitations in carbon and nitrogen supply to the ear, favoring abortion after fertilization.

On the other hand, WILSON \& ALLISON (1979) stated that it was not clear to what extent the greater post-flowering loss of kernels as population increased was caused by competition between kernels for the available supply of assimilates in the plant. They argued that maize normally seems able to make more assimilate available for grain growth than it is required. Moreover, some abortion of kernels apparently occurs soon after flowering, when the plant is producing considerably more assimilate than the kernels require and labile dry matter is accumulating in the stem (JACOBS \& PEARSEN, 1991). SALVADOR (1984) observed that ovules located at the tip of the ear were especially susceptible to abortion under stressful conditions. They contained smaller amounts of nucellus, a maternal plant tissue that may play an important role in supporting kernel metabolism immediately after fertilization. Therefore, the abortion of young kernels promoted by high plant densities may be largely a consequence of restrictions affecting the plant before the beginning of grain filling.

\subsection{Kernel dry matter:}

A final detrimental effect of high plant population on yield components is observed through reduction in the final weight per grain. The rather large differences in weight per grain observed at different plant populations may result from differences in the initial size of the spikelets, in growth rates during the exponential and linear (starch deposition) phases of grain growth or in the duration of those phases (JONES et al., 1985). LEMCOFF \& LOOMIS (1986) observed that the initial grain weight, $\mathrm{W}_{0}$, after pollination was a key factor in the early growth of the kernel. At high plant populations, $\mathrm{W}_{0}$ was smaller, which could in turn be due to delay in development (later initiation of spikelets) or smaller initial size of the spikelet primordia.

The lower number and size of potential kernels during the beginning of the reproductive stage may also impact the filling rates, in both exponential and linear phases, as well as the length of the effective filling period (JONES et al., 1985). Potential sink capacity and strength are established during an early cell-division phase (SALVADOR \& PEARCE, 1995). Final kernel mass correlates strongly with numbers of cells and starch granules formed, particularly in the endosperm tissue, representing about $85 \%$ of the mass of mature maize kernels. Therefore, under high plant populations, yield may be restricted by limitations in the capacity for endosperm growth either by number, size or activity of endosperm cells (SALVADOR, 1984).

There is also an interaction between kernel position and number in terms of competition for substrates required for growth, which is more accentuated at high plant density. Florets at the tip of the ear are originally smaller and silk later than the basal ones. The growth stage when maximum endosperm cell number occurs is delayed for the tip grains, which also contain fewer endosperm cells and starch granules and exhibit a lower rate of filling than basal kernels (JONES et al., 1985).

\section{Increase in the tolerance to high plant densities of modern maize hybrids:}

\subsection{General considerations:}

Among the major agronomic crops, maize is likely the one that has presented the greatest increments in grain yield during the last fifty years (RUSSELL, 1991). The improvements in maize grain yield have been due to improved production practices, such as higher soil fertility, better weed control, increased plant densities and narrow row spacing, along with the use of genetically superior hybrids (TOLLENAAR et al., 1994). Grain yield improvement of maize hybrids has been associated with increased tolerance to high plant densities which is a reflection of increased stress tolerance (TOLLENAAR $\boldsymbol{e t}$ al., 1997).

Almost all commercial hybrid yield test programs have emphasized mean yield as the main criterion for advancement. An important component of that mean has been stability of yield across a range of environments, a key factor to increase overall hybrid stress tolerance. Much of the improvement observed in the ability of modern inbreds and hybrids to withstand high populations results from selfing procedures in nurseries stressed by high plant densities.

Therefore, high plant populations and selfing have been useful management tools for eliciting maize tolerance to stressful environments. Selfing relies on a short anthesis-silking interval 
(ASI) for success. Poorly synchronized plants are automatically eliminated. Consequently, a great deal of selection for reduced ASI has routinely taken place in breeding nurseries.

Selection against silk delay has been one of the most effective breeding methods to improve maize tolerance to environmental stresses (EDMEADES et al., 1993). Plants with little silk delay use solar radiation, soil nutrients and soil water more effectively. Silk delay is highly heritable, which improves its value as a selection criterion against barrenness (BOLAGNOS \& EDMEADES, 1996).

\subsection{Traits associated with improved maize tolerance to high plant densities:}

Selection procedures used to improve maize endurance in a wide range of environments brought a series of morphological and physiological modifications that have contributed to improve maize adaptation to high plant densities.

\subsubsection{Plant architecture:}

Most modern hybrids currently cultivated in Southern Brazil are earlier, have a smaller plant height, lower leaf number and more upright leaves in comparison to the cultivars used in the past (ALMEIDA et al, 2000). With a smaller and less leafy plant, the level of interference or competition of each individual over the others is lower (SANGOI \& SALVADOR, 1998a). The production of a smaller plant, with shorter stems, fewer and more erect leaves reduces relative production and maintenance costs (e.g. water, nutrients and assimilates) per plant (LOOMIS \& CONNOR, 1992).

A lower amount of vegetative biomass per plant allows the use of more individuals per area, which in turn increases leaf area index (LAI). Increments in LAI provide more effective light interception (TOLLENAAR et al., 1997). With greater amounts of solar radiation intercepted, increases in dry matter production by the whole community are obtained (SINCLAIR, 1998). Changes in plant architecture also permit modern hybrids to attain higher leaf photosynthetic rates than older hybrids at high plant densities (DWYER et al., 1991). This also promotes improved radiation use efficiency during grain filling, which further contributes to the production of more kernels per plant and higher grain yield (TOLLENAAR $\boldsymbol{e t}$ al., 1992). A more compact plant architecture has also been important in enhancing maize standability at high densities, reducing problems with stalk and root lodging (SANGOI et al., 2000).

\subsubsection{Inflorescence development:}

Maize is the only economically important grass that flowers monoeciously (SANGOI, 1996). Because the tassel is apical and differentiates first, it has developmental priority over the ears (SANGOI \& SALVADOR, 1998b). This protandrous behavior is accentuated at high plant densities, assuring pollen production and dispersion at the expense of ear and silk development (SANGOI \& SALVADOR, 1998c)

The higher number of ears per plant and the lower number of barren plants achieved by modern hybrids at high plant densities may also be related to a better developmental balance between male and female inflorescences. SMITH (1982) noticed that density-tolerant genotypes were characterized by reduced tassel size, rapid growth of the first ear, short pollen-shed-to-silking interval and a more efficient production of grain per unit of leaf area. More recently, SANGOI \& SALVADOR (1998b) and SANGOI et al. (1998b) verified that grain yield of modern maize hybrids did not increase with detasseling even at high plant densities. This provides further evidence that apical dominance of the tassel over the ears is less intense in modern hybrids (SANGOI et al., 1998b).

The selection pressure applied by plant breeders to adapt current genotypes to the stress of extreme crowding resulted in a plant that invests fewer resources on its male inflorescence. Smaller tassels reflect and re-radiate lower amounts of solar radiation potentially available to the photosynthetic canopy (SANGOI, 1996). They also require fewer nutrients and photoassimilates to support their development (SANGOI \& SALVADOR, 1996). Moreover, they produce less auxin, decreasing the possibility that auxin derived from the apical inflorescence exerts a hyperauxin effect on the growth of lateral branches leading to barrenness (SANGOI, 1996).

Overall, selection to improve maize tolerance to stressful conditions decreased apical dominance and consequently the plant's protandry. Consequently, modern genotypes have a shorter interval between tassel and ear differentiation (SANGOI et al., 1998b). The decrease in tassel developmental rates and reduction on its sink strength have been instrumental to better synchronize pollen shed and silking extrusion, contributing decisively to the short anthesis-silking interval observed when modern hybrids were grown 
at high plant densities (PEIXOTO et al., 1997; SILVA et al., 1998). Since maize has a short and definite period of flowering and pollen remains viable for a brief period of time, the better synchrony between silk emergence and pollen shed of modern hybrids accounts for a higher rate of sexual fertilization, enhancing kernel set and leading ultimately to more efficient production of grain per unit leaf area.

\section{CONCLUSION}

Maize susceptibility to variations in plant density has generated intense research effort with a view to better understand how changes in the number of individuals per area impact grain yield definition and to identify optimum population densities for this species under a wide range of environmental and management situations.

Maize has undergone a remarkable increase in grain yield potential during this century due to heterosis and the release of more productive genotypes. The development of hybrids with greater tolerance to higher plant population was an important contributing factor to that accomplishment.

Maize must be grown at high plant populations to maximize interception of solar radiation. However, at high plant densities efficient conversion of intercepted solar radiation to grain may be limited by apical dominance, protandry, delays in ear differentiation, asynchronous flowering and barrenness. Changes in plant morphology and phenology increased the ability of the whole crop community to utilize available resources through increased population density.

The development of earlier hybrids, with shorter plant height, lower leaf number, upright leaves, smaller tassels and more synchronized floral development improved maize ability to withstand high plant densities without presenting a higher percentage of barren plants. The use of higher plant populations enabled maize to intercept virtually all the available solar radiation earlier in the season, transforming this energy into storage carbohydrates and other foods in more grains per area.

The breeding effort during the second half of this century has lead to a plant designed for maximum energy storage and minimum energy wastage with excessive vegetation. This new ideotype has provided an important basis to accomplish a greater grain yield plateau with the use of higher plant populations. Most of the physiological and morphological changes maize has undergone were consequences of the high density selection pressure applied by plant breeders at their inbred nursery fields. The challenge for the future is to fully understand how each of the modified traits described herein contributed individually and collectively to maize endurance to high population stress. Once that knowledge is pursued, the next task is to find out how they can be genetically manipulated so that man can keep on pushing maize optimum plant population and grain yield to higher values.

\section{REFERENCES}

ALDRICH, S.R., SCOTT, W.O., HOEFT, R.G. Modern corn production. 2 ed. Champaign : A and L Publ., 1986. 357p.

ALMEIDA, M.L., de. Modificação do afilhamento de trigo e aveia pela qualidade da luz. Porto Alegre, RS, 1998. 120p. Dissertação (Doutorado em Fitotecnia) - Curso de Pósgraduação em Agronomia, Universidade Federal do Rio Grande do Sul, 1998.

ALMEIDA, M.L., de, SANGOI, L. Aumento da densidade de plantas de milho para regiões de curta estação estival de crescimento. Pesquisa Agropecuária Gaúcha, Porto Alegre, v.2, n.2, p.179-183, 1996.

ALMEIDA, M.L., de, MEROTTO Jr., A., SANGOI, L., et al. Incremento na densidade de plantas: uma alternativa para aumentar o rendimento de grãos de milho em regiões de curta estação estival de crescimento. Ciência Rural, Santa Maria, v.30, n.1, p.23-29, 2000.

ANDERSON, I.C. Crop management. Ames : Iowa State University, 1995. 52p. (Agronomy 516 Course Work, 1).

BOLAÑOS, J., EDMEADES, G. The importance of the anthesissilking interval in breeding for drought tolerance in tropical maize. Field Crops Research, Amsterdan, v.31, n.2, p.233252, 1996.

BULLOCK, D., KHAN, S., RAYBURN, A. Soybean responses to narrow rows is largely due to enhanced early growth. Crop Science, Madison, v.38, n.4, p.1011-1016, 1998.

BUNTZEN, S. New wave of interest in narrow row corn. Crop Insights, Urbana, v.51, n.6, p.598-602, 1992.

CASAL, J.J., DEREGIBUS, V.A., SÁNCHEZ, R.A. Variations in tiller dynamics and morphology in Lolium multiflorum Lam. vegetative and reproductive plants as affected by differences in red/far-red irradiation. Annals of Botany, London, v.56, p.533-559, 1985.

DWYER, L.M., TOLLENAR, M., STEWART, D.W. Changes in plant density dependence of leaf photosynthesis of maize (Zea mays L.) hybrids, 1959 to 1988 . Canadian Journal Plant Science, Quebec, v.71, p.1-11, 1991.

EDMEADES, G.O., BOLAÑOS, J., LAFFITE, A.R. Progress in breeding for drought tolerance in maize. In: FOURTYSEVENTH ANNUAL CORN \& SORGHUM RESEARCH CONFERENCE, 1993, Chicago, IL. Proceedings... Washington: American Seed Trade Association, 1993. v.47, 280p. p.93-111. 
GARDNER, F.P., PEARCE, R.B., MITCHELl, R.L. Physiology of crop plants. Ames : Iowa State University, 1985. 327p.

JACOBS, B.J., PEARSON, C.J. Potential yield of maize. determined by rates of growth and development of ears. Field Crops Research, Amsterdam, v.27, n.2, p.281-298, 1991.

JONES, R.J., ROESSLER, J., QUATTAR, S. Thermal environment during endosperm cell division in maize: effects on number of endosperm cells and starch granules. Crop Science, Madison, v. 25, n. 4, p. 830-834, 1985.

KASPERBAUER, M.J., KARLEN, D.L. Plant spacing and reflected far-red light effects on phytochrome-regulated photosynthate allocation in corn seedlings. Crop Science, Madison, v. 34, n.6, p. 1564-1569, 1994.

LAUER, J. Should I be planting my corn at a 30-inch row spacing? Wisconsin Crop Manager, Madison, v.1, n.6, p.311-314, 1994

LEMCOFF, J.H., LOOMIS, R.S. Nitrogen influences on yield determination in maize. Crop Science, Madison, v.26, n.5, p.1017-1022, 1986

LEMCOFF, J.H., LOOMIS, R.S. Nitrogen and density influences on silk emergence, endosperm development, and grain yield of maize (Zea mays L.). Field Crops Research, Amsterdam, v.38, n.1, p.63-72, 1994

LOOMIS, R.S., CONNORS, D.J. Crop ecology: productivity and management in agricultural systems. Cambridge Cambridge University, 1992. 550p.

MATZENAUER, R., BERGAMASCHI, H., BERLATO, M., $\boldsymbol{e}$ al. Evapotranspiração da cultura do milho. I - Efeito de épocas de semeadura. Revista Brasileira de Agrometeorolgia, Santa Maria, v.6, n.1, p.9-14, 1998.

MEROTTO Jr., A., ALMEIDA., M.L. de, FUCKS, O. Aumento do rendimento de grãos de milho através do aumento da população de plantas. Ciência Rural, Santa Maria, v.27, n.4, p.549-554, 1997.

OLSON, R.A., SANDERS, D.H. Maize production. In: SPRAGUE, G.F. DUDLEY, J.W. Corn and corn improvement. Madison : American Society of Agronomy, 1988. Cap.11, p.639-686.

PEIXOTO, C.M., SILVA, P.R.F.,da, REZER, F., et al. Produtividade de híbridos de milho em função da densidade de plantas, em dois níveis de manejo da água e da adubação. Pesquisa Agropecuária Gaúcha, Porto Alegre, v.3, n.1, p.63-71, 1997

RITCHIE, S.W.; HANWAY, J.J. How a corn plant develops. Ames : Iowa State University of Science and Technology, 1992. 26p. (Special Report, 48).

RUSSEL, W.A. Genetic improvement of maize yields. Advances in Agronomy, Cambridge, v.46, n.1, p.245-298, 1991.

SALISBURRY, F.B., ROSS, C.W. Plant physiology. 4 ed. Belmont: Wadsworth, 1992. 681p.

SALVADOR, R.J. Assimilate uptake by maize (Zea mays L.) kernels as affected by source-sink manipulations. Ames,
IA, 1984. 185p. Dissertation (M.Sc. in Crop production and physiology) - Iowa State University, 1984.

SALVADOR, R.J., PEARCE, R.B. Proposed standard system of nomenclature for maize grain filling events and concepts. Maydica, Bergamo, v.40, n.1, p.141-146, 1995.

SANGOI, L. Aptidão dos campos de Lages (SC) para produção de milho em diferentes épocas de semeadura. Pesquisa Agropecuária Brasileira, Brasília, v.28, n.1, p.51-63, 1993.

SANGOI, L. An ideotype of maize for conditions of high temperature and low moisture. Ames, IA, 1995. 350p. Thesis (Ph.D. in Crop production and Physiology) - Iowa State Universtiy, 1996.

SANGOI, L., SALVADOR, R.J. Agronomic performace of male-sterile and fertile maize genotypes at two plant populations. Ciência Rural, Santa Maria, v.26, n.3, p.377388, 1996.

SANGOI, L., SALVADOR, R.J. Influence of plant height and leaf number on maize production at high plant densities. Pesquisa Agropecuária Brasileira, Brasília, v.33, n.3, p.297-306, 1998a.

SANGOI, L., SALVADOR, R.J. Effect of maize detasseling on grain yield tolerance to high plant density and drought stress. Pesquisa Agropecuária Brasileira, Brasília, v.33, n.5, p.677-684, 1998b.

SANGOI, L., SALVADOR, R.J. Maize susceptibility to drought at flowering: a new approach to overcome the problem. Ciência Rural, Santa Maria, v.28, n.4, p.699-706, 1998c.

SANGOI, L., ENDER, M., GUIDOLIN, A.F., et al. Evolução da resistência a doenças de híbridos de milho de diferentes épocas em três populações de planta. Revista Ciência Rural, Santa Maria, v.30, n.1, p.17-21, 2000.

SANGOI, L., ENDER, M., MEROTTO Jr., A., et al. Redução do espaçamento entre linhas para cultivares de milho de ciclos contrastantes em duas épocas de semeadura. In: REUNIÃO ANUAL DO MILHO E SORGO, 1997. Erechim, RS Anais... Erechim : COTREL/EMATER/FEPAGRO, 1998a. 382p. p. 26-30.

SANGOI, L., ENDER, M., MEROTTO Jr., A., et al. Dominância apical de híbridos de milho de diferentes épocas em três densidades de semeadura. In: REUNIÃO ANUAL DO MILHO E SORGO, 42, 1997. Erechim, RS. Anais... Erechim ; COTREL/EMATER/FEPAGRO, 1998b. 382p. p.31-36.

SILVA, P.R.F. da. Densidade e arranjo de plantas em milho. In: CONGRESSO NACIONAL DE MILHO E SORGO, 19, 1992, Porto Alegre, RS. Conferências... Porto Alegre : Secretaria da Agricultura - CIENTEC-ABMS, 1992. p.291294.

SILVA, P.R.F. da. ARGENTA, G., REZERA, F., et al. Resposta de híbridos de milho à densidade de plantas, em três épocas de semeadura. In: REUNIÃO ANUAL DO MILHO E SORGO, 42, 1997. Erechim, RS. Anais... Erechim : COTREL/EMATER/FEPAGRO, 1998. 382p. p. 13-21.

SINCLAIR, T.R. Historical changes in harvest index and crop nitrogen accumulation. Crop Science, Madison, v.38, n.2, p.638-643, 1998. 
SMITH, C.S., MOCK, J.J., CROSBIE, T.M. Variability for morphological and physiological traits associated with barrenness and grain yield in maize population, Iowa Upright Leaf Synthetic 1. Crop Science, Madison, v.22, n.4, p.828$832,1982$.

SWANK, J.C., BELOW, F.E., LAMBERT, R.J., et al. Interaction of carbon and nitrogen metabolism in the productivity of maize. Plant Physiology, Bethesda, v.70, n.5, p.1185-1190, 1982.

TETIO-KAGHO, F., GARDNER, F.P. Responses of maize to plant population density. I. Canopy development, light relationships, and vegetative growth. Agronomy Journal, Madison, v.80, n.5, p.930-935, 1988 .

TOLLENAAR, M. Is low plant density a stress in maize? Maydica, Bergamo, v.37, n.2, p.305-311, 1992.

TOLLENAAR, M.,. DAYNARD, T. B. Leaf senescence in shortseason maize hybrids. Canadian Journal of Plant Science, Toronto, v.58, n.3, p.869-874, 1978.

TOLLENAAR, M., McCUllOUGH, D.E., DWYER, L.M.
Physiological basis of the genetic improvement of corn. In: SLAFER, G.A. Genetic improvement of field crops. New York : Marcel Dekker, 1994. Ch.4, p.183-236.

TOLLENAAR, M., AGUILERA, A., NISSANKA, S.P. Grain yield is reduced more by weed interference in an old than in a new maize hybrid. Agronomy Journal, Madison, v.89, n.2, p.239-246, 1997.

WESTGATE, M.E. Seed formation in maize during drought. In: BOOTE, K.J., BENNETT, J.M., SINCLAIR, T.R.,. et al. Physiology and determination of crop yield. Madison : American Society of Agronomy, 1994. Cap.15, p.361-364.

WESTGATE, M.E., THOMPSON, D.L. Water deficits and reproduction in maize: response of the reproductive tissue to water deficits at anthesis and mid-grain filling. Plant Physiology, Bethesda, v.91, n.4, p.862-867, 1989.

WILSON, J.H., ALLISON, J.C.S. Effect of plant population on ear differentiation and growth in maize. Annals of Applied Biology, London, v.90, n.1, p.127-132, 1979.

Ciência Rural, v. 31, n. 1, 2000. 